\title{
What is Holding Back EU Exports to China?
}

\author{
Simon J. Evenett \\ University of St. Gallen, St. Gallen, Switzerland \\ Johannes Fritz \\ University of St. Gallen, St. Gallen, Switzerland \\ Martin Wermelinger \\ University of St. Gallen, St. Gallen, Switzerland
}

\begin{abstract}
Access to the fast-growing Chinese economy is prized by policymakers and business people but concerns that European firms are missing out on the Chinese boom have led to soul-searching concerning Europe's competitiveness and to criticism leveled at Chinese protectionism. This paper examines the factors affecting the export share to China over the period of 2000 to 2010 of the first 15 members to join the European Union. China's growing share in world spending is found to be the most important factor in this respect but labour cost differentials within Europe, commercial diplomacy, and export promotion policies by China have also contributed.
\end{abstract}

\section{JEL Classifications: F14}

Key words: European Union, China, Exports, Protectionism, Competitiveness, Commercial Diplomacy

\footnotetext{
* Corresponding Author: Simon J. Evenett; Department of Economics, University of St. Gallen, Bodanstrasse 8, St. Gallen 9000, Switzerland; Tel: +41 712242315, Fax: +41 712242298, E-mail: simon.evenett@unisg.ch.

Co-Author: Johannes Fritz; Department of Economics, University of St. Gallen, Bodanstrasse 8, St. Gallen 9000, Switzerland; Tel: +41 712242340, Fax: +41 712242298, E-mail: johannes.fritz@unisg.ch;

Martin Wermelinger; Department of Economics, University of St. Gallen, Bodanstrasse 8, St. Gallen 9000, Switzerland; Tel: +41 712242340, Fax: +41 712242298, E-mail: martin.wermelinger@unisg.ch.
} 


\section{Introduction}

High rates of economic growth in China, India, and other Asian nations have accounted for their growing share in global spending. Most forecasts anticipate that these shares will continue to rise in the decades ahead (PWC 2013). Firms in industrialised economies eyeing new commercial opportunities have sought to expand their sales, specifically their exports, to these fast growing markets. As the second largest economy in the world, these considerations apply, in particular, to China. While Chinese growth holds out the prospect for greater cross-border trade, there is dissatisfaction with the rate at which Western firms have been able to penetrate markets in the Middle Kingdom. Some point to supply-side weaknesses at home and others to Chinese protectionism, which critic's, claim has widened in scope since the global economic crisis began.

The purpose of this paper is to estimate the relative importance of the different supplyside, demand-side, and policy-related factors responsible for the share of exports that each of the initial 15 members of the European Union (EU) shipped to China during the years 2000 to 2010. The inclusion of the latter years was deliberate since it is of interest whether and by which means the recent global economic crisis affected EU exports to China. The policy instruments considered in this paper go beyond those found in most studies in crisis-era trade response. For one, information on the number of times each member state government has complained about Chinese dumping on European markets was gathered to see whether the exports from frequent complainers were treated more leniently by the Chinese or whether they became the target of Chinese retaliation. Moreover, the impact of European commercial missions to China and state aid to European firms were estimated.

While this study is likely to be of interest to policymakers and government officials, given the number of high-profile trade disputes between China and the EU in 2012 and 2013, the analysis undertaken here may be of interest to academic researchers as well. Emerging markets have grown faster than the world average for some time, effectively constituting a major shift in global expenditures and providing an opportunity to study how demand-side factors influence trade flows. ${ }^{2}$ The frictionless gravity equation implies that the share of a country's exports to a foreign nation should equal the latter's share of the world GDP (Anderson 1979). This observation provides an important benchmark and begs the question: How much of the observed changes in EU exports to China reflect "mundane" demand shifts rather than more

\footnotetext{
${ }^{1}$ See the regular reports prepared by the United States Trade Representative and the European Commission's Directorate-General for Trade on the policies implemented by foreign governments that harm American and European commercial interests, respectively.

${ }^{2}$ This is certainly not the first paper to examine the effect of demand patterns on trade. In this regard, the Linder Hypothesis has received some attention over the years (Linder 1961). Later on, consideration was given on whether departures from the traditional assumption of identical homothetic preferences could better account for observed variation in trade flows (Hunter 1991, Hunter, and Markusen 1988).
} 
controversial policy-related factors, such as Chinese intervention or fungible European state aids? Moreover, our analysis of export response will add to the growing literature on the impact of the global economic crisis on trade flows (Baldwin 2009). ${ }^{3}$

The remainder of this paper is organised as follows. To provide a factual grounding for the subsequent econometric analysis, the next section includes a discussion of two stylised facts involving the growth of EU exports to China since 2000. Possible hypotheses that might account for these facts are also spelt out. In the third section, the econometric approach taken and data used are described. The econometric results and the decomposition of EU export growth that they imply are reported in Section IV. Concluding remarks are found in Section V.

\section{Stylised Facts and 10 Hypotheses}

For each of the first 15 nations to join the European Union (the "EU15" from here on) an exploratory data analysis was conducted on the share of their exports to China and to the Rest of the World (ROW) for the years 2000 to 2010. For this purpose the data for the years 2009 and 2010 relate to the crisis era, allowing for comparisons before and after the onset of the global economic crisis. The principal stylised facts can be seen in the plots presented in Figures 1 and $2^{4}$

Before and after the global economic crisis, export growth by the EU15 to China was positively correlated to export growth to the ROW (Figure 1). Before the crisis, in only two EU member states (Sweden and Finland) was export growth to the ROW faster than that to China. For the most part, then, the share of exports destined for China rose before the crisis. Indeed Portugal, Spain, and Ireland - three of the countries that would find themselves in dire financial straits during the crisis - actually saw their exports to China grow much faster than to the ROW before the crisis struck. Whatever deep-seated "competitiveness" problems may have been building up in these countries before the crisis, it was not obvious that they harmed these countries' export performance to China, relative to their EU15 peers.

The crisis era did see some changes in EU15 export behaviour. Differences across the EU15 in export growth rates to China widened, as can be seen from the varying fortunes of Luxembourg, Portugal, and Greece. ${ }^{5}$ Moreover, every EU15 country aside from Luxembourg saw its exports rise to China from 2008 to 2010 while its exports to the ROW fell over the

\footnotetext{
3 Other notable recent contributions on the effects of various forms of crisis-era protectionism include Kee, Neagu, and Nicita (2010) and Eaton, Kortum, Neiman, and Romalis (2011). Such studies are to be distinguished from the larger number of studies documenting the resort to protectionism and other beggar-thy-neighbour activities since the global economic crisis began.

${ }^{4}$ Summary statistics on the EU15's exports to China are reported later in the paper in Table 1.

${ }^{5}$ Luxembourg saw an overall reduction in its exports to China from 2008 to 2010 whereas Portugal and Greece experienced sharp increases.
} 
same time horizon. ${ }^{6}$ None of the EU15 members that received financial bailouts during the crisis underperformed their peers (compare, for example, Greece and Portugal's above-the-line performance between 2008 and 2010 with that of Denmark and the Netherlands).

There is also some evidence of convergence across the EU15 in the share of exports destined for China during the crisis era (Figure 2). The share of national exports going to China in 2008 is negatively correlated with the average growth rate of exports to China in the two years that followed. Germany appears to be a clear exception, combining a high initial export share (in 2008) and average levels of subsequent export growth. In this regard, Finland is probably an outlier too, a point taken up during the econometric analysis.

\section{A. Potential explanations}

What hypotheses might account for the variation in export performance across the EU15 reported in Figures 1 and 2. First, there could be member state-specific factors that influence exports. Increased government spending on goods by EU15 member states could induce home market effects, ${ }^{7}$ resulting in higher exports in sectors where firms have economies of scale. This first hypothesis (H1) implies a positive relationship between government spending on goods and exports. Alternatively, more domestic production could be diverted to government contracts, thereby crowding out exports and rendering the predicted sign unclear.

Member states that grant larger amounts of state aid may enable their exporters to undercut foreign rivals and win larger numbers of export contracts. This is the second hypothesis (H2). Member states whose manufacturing firms pay on average lower hourly compensation levels may be able to undercut rivals, thereby raising exports. Such is the third hypothesis (H3).

It should be noted that these three hypotheses refer to the level of overall exports. What is of interest here is whether the associated factors account for higher export shares to China. The three hypotheses have to be assessed, then, as to whether the factors concerned give rise to any particular edge in competing in the Chinese market. Moreover, should any of these hypotheses be rejected by the data, it does not mean they have no impact on overall exports, just the shares of exports to China.

A fourth hypothesis (H4) relates to differences in the types of good that an EU15 nation exports and the types of good that China imports. When the composition of the former overlaps with the composition of the latter, the export share is hypothesised to be larger.

A fifth related hypothesis (H5) is that EU15 member states may vary to the extent they ship the types of products that China imports for use in its export industries. Given the frequent and

\footnotetext{
${ }^{6}$ On Figure 1 the plot for 2008-10 lies to the left of the vertical axis, whereas the plot for 2000-2008 lies to the right.

${ }^{7}$ Krugman (1991).

${ }^{8}$ Alternatively, the granting of state aid may reflect an inability to compete unhindered in world markets, in which case more state aid may well be correlated with fewer exports.
} 
far-reaching attempts to influence Chinese export levels through changes in the VAT rebates paid to Chinese exporters on the items that they import (see Evenett, Fritz, and Yang 2012 for details), it will be interesting to see if the extent of such rebating interacts with an index of the similarity between an EU15 nation's exports and China's import mix accounts for some of the variation in export behaviour across Europe.

A sixth hypothesis (H6) arises from China's growing share of world GDP. As the share of the world's spending undertaken by a country increases, it will tend to import a greater proportion of each trading partner's exports. Differences across the EU15 in the movements of their currencies against the Chinese renminbi are another potential explanation, a seventh hypothesis (H7). It is worth bearing in mind in this regard that not every EU15 nation is a member of the Eurozone (allowing for intra-EU15 exchange rate variation) and that accusations of Chinese currency manipulation were made during the decade studied here.

Turning to other policy-related hypotheses, one source of variation across the EU15 is the extent to which export-promoting commercial diplomacy is undertaken by the member states. An eighth hypothesis (H8) is that exports are higher for EU15 nations that send government ministers more often on official visits to China. The remaining two hypotheses concern protectionism. The ninth hypothesis (H9) relates to the frequency with which a member state has encouraged the European Commission to take action against dumped Chinese exports in the past and whether the affects China's treatment of that member state's exports. The effect could be positive or negative: EU15 member states with a reputation for complaining may encourage the Chinese to accommodate their exports. Likewise, complainers may become the target of Chinese retaliation. The tenth hypothesis (H10) is that the more frequent the Chinese resort to trade barriers against an EU15 member state, the lower the latter's export shares become.

Overall, then, these ten hypotheses relate to two demand-side, ${ }^{10}$ three supply-side (competitiveness), ${ }^{11}$ and five policy-induced ${ }^{12}$ determinants of export performance. The purpose of the following econometric analysis is to assess the relative importance of these factors.

\footnotetext{
${ }^{9}$ More generous rebates to Chinese firms on their VAT payments for imported inputs, which are used solely in the production of exports, increase the profitability of exporting relative to selling the good on the national market. China is not alone in offering such rebates; however, China is unique among the large trading nations for varying its VAT rebates so often. The ability to alter rebates on a product-by-product basis allows the Chinese authorities to target specific exports. As argued in Evenett, Fritz, and Yang (2012), the scale of this practice in China is tantamount to a system of export management.

${ }^{10}$ Hypotheses H4 and H6.

${ }^{11}$ Hypotheses H1, H3, and H7. To the extent that the "crowding out" explanation applies in H1, there is a clear demand-side component to this hypothesis as well.

${ }^{12}$ Hypotheses H2, H5, H8, H9, and H10.
} 


\section{Econometric Approach and Data}

While the overall goal of the empirical strategy employed here is to ascertain the relative importance of the factors that determined the share of EU15 exports sent to China between 2000 and 2010, the design of that strategy took into account a number of considerations arising from empirical research on bilateral trade flows. First, given the strong preference among researchers in international trade for some link to an underlying economic theory (Leamer and Levinsohn 2005, Feenstra 2003), recall the prediction of the frictionless gravity equation that the share of a nation's exports shipped to a trading partner equals the latter's share of world GDP (Anderson 1979). We used this prediction as a benchmark for export shares. Essentially, our econometric strategy amounts to examining the extent to which actual EU15 export shares to China from 2000 to 2010 departed from that benchmark in ways that were correlated with other plausible determinants of export performance (see the hypotheses described in the previous section.) Our approach, then, was not theory-free although it would be wrong to give our findings a structural interpretation.

Our approach does differ from that of traditional gravity equations, which seek to account for the variation across country pairs in the total value of bilateral trade. Gravity approaches require, therefore, taking a stand on the total value of goods that a nation has available to export. ${ }^{13}$ By focusing on the share of a nation's goods sold to a trading partner, our approach does not require any assumptions on the overall amount of goods produced or exported. Our choice of dependent variables speaks precisely to the reorientation of exports that many governments and business people say they seek to accomplish given the return of Asia to global economic pre-eminence. Like gravity equations, however, we account for time-invariant, unobserved heterogenity (Baldwin and Tagloni 2006).

Note $S_{j, t}$ as the share of country $j$ 's exports shipped to China in year $t$; $\mathrm{CGDP}_{\mathrm{t}}$ as China's share of world GDP in year $t ; I_{j, t}$ as a vector of independent variables that are hypothesised to determine $S_{j, t}$ other than $\mathrm{CGDP}_{i} ; \alpha$ as a constant; and $\varepsilon_{j, t}$ as a well-behaved error term. The first step is to estimate the following regression equation:

$$
S_{j, t}=\alpha+\beta \mathrm{CGDP}_{t}+\gamma I_{j, t}+\varepsilon_{j, t} \quad j: \mathrm{EU} 15, t=2000, \ldots ., 2010
$$

Concerns about outliers demand a re-estimation of this equation with and without Germany and Finland. Concerns about heteroskedacity and a relatively small sample size (a crosssectional dimension of 15 and a time series dimension of 11) led to the use of HC3 standard errors, which arose from a technique specifically designed by Davidson and Mackinnon to

\footnotetext{
${ }^{13}$ As Anderson (1979) has shown, various factors such as the size of the non-traded goods sector can affect the amount of goods that a nation can potentially export.
} 
estimate the variance-covariance matrix in samples of this type (Davidson and McKinnon 2003). ${ }^{14}$

Ordinary Least Squares with exporter-specific fixed effects were used to recover the parameter estimates. In addition to recovering the residuals, the parameter estimates were also used to decompose the change in the dependent variable between 2008 and 2010 into changes attributable to each of the independent variables, $\mathrm{CGDP}_{t}$ and $I_{j, t}$ In this manner, then, the quantitative as well as the statistical significance of each determinant of EU15 export shares could be assessed, shedding light on which factors if any are really holding back EU exports to China.

\section{A. Data and summary statistics}

Data from the United Nations' COMTRADE database were used to calculate the share of each EU15 member's total exports, which were shipped to China in a given year, $\mathrm{S}_{j, t}$ this being the dependent variable of this study. ${ }^{15}$ The information contained in the World Development Indicators database of the World Bank was used to calculate the share of each EU15 nation's GDP, which was accounted for by government consumption expenditure, providing the independent variable to analyse the impact of home market and crowding out effects mentioned in H1. As noted earlier, the relevant estimated parameter could be positive or negative.

Data from the Directorate-General of Competition of the European Commission were used to compute on an annual basis the total value of state aid offered by an EU member state as a share of its GDP. This variable is relevant for assessing H2. Given the substantial resort to subsidies during the crisis era, the inclusion of this independent variable may be of considerable interest, although concerns about under-reporting or misclassification of such subsidies should be borne in mind. Again, as argued earlier, depending on how subsidies are allocated, the sign of the estimated parameter here could be positive or negative.

Indexing hourly compensation costs in German manufacturing in 1997 at 100 and then computing the relative nominal hourly labour costs of Germany and every other EU15 member for the years 2000 to 2010 resulted in an independent variable to assess H3. The independent variable was constructed using data from the US Department of Labor's Bureau of Labor Statistics and was lagged three years to limit concerns about simultaneity. The expected sign of the estimated parameter was negative, reflecting the adverse effect of higher wages relative to Germany on export shares to China.

\footnotetext{
${ }^{14}$ This estimator for standard errors in small samples is available in standard econometric packages, such as STATA.

${ }^{15}$ Note the total value of exports of a country $j$ in year $t$ to all foreign nations by $X_{j r}$. The total value of exports by country $j$ in year $t$ to China is $x_{j t}$. The dependent variable is computed as follows: $S_{j, t}=x_{j t} / X_{j t}$.
} 
To compare the overlap between the types of goods an EU15 nation exports to China and the types of goods that China imports, each product line in the United Nations' COMTRADE database was first categorised as either raw material, intermediate good, consumer good, or capital good. For each EU15 member state in each year of the sample, the shares of its total exports to ROW that fell under the four categories above were, then, calculated. Likewise, for China in each year of the sample, the share of its total imports from the rest of the world (excluding the EU15), which fell under the same four categories, was calculated. If an EU15 country exports the types of goods that China wants to buy, then the respective shares of the former and the latter should be similar looking across these four categories. A natural index of dissimilarity was the sum across the four categories of the square of the differences in the member state's and China's shares. That index was computed for each EU15 member and for every year and was referred to here as the Differences in Composition Index. This index was used to evaluate $\mathrm{H} 4$. The expected sign of the parameter estimate here is negative.

Demand for European goods may also rise because of attempts to bolster Chinese exports. One means that China uses to promote exports for which there is product-level and intertemporal variation is employing rebates on Value Added Tax payments by Chinese firms for items that they import abroad and then use in the production of exports. Data on the share of Chinese exports covered by VAT rebates in a given year ${ }^{16}$ were interacted with the Differences in Composition Index to examine whether total Chinese exports accounted for some of the differences in EU15 exports to China, along the lines of H5. Like H4, the expected sign of the estimated parameter was negative.

The share of China's GDP in world GDP in a given year was computed from the World Bank data source mentioned earlier. This generated the independent variable $C G D P_{t}$, which corresponds to the prediction for export shares generated by a frictionless gravity equation model (H6). The expected sign on this independent variable was positive.

Data on annual nominal exchange rates from the European Central Bank were used to create an index, normalised to the year 2000, to capture the annual changes in the bilateral exchange rate between an EU15 member state and China, per H7. Given the traditional definition of nominal exchange rates employed here - namely, that of the number of units of home currency needed to buy a unit of foreign currency - the expected sign on this independent variable was positive.

Using the FACTIVA database of news stories made available by Dow Jones \& Company, which included media sources in English, German, and French, a count was made for each EU15 member state of the number of times its government ministers visited China during a given year. Business people frequently accompany such visits and the associated commercial diplomacy could lead to contracts being awarded by Chinese government ministries or by

\footnotetext{
${ }^{16}$ This data was first reported in English by Evenett, Fritz, and Yang (2012), who documented the largeness in scale of this export management practice. During the crisis era the Chinese government changed its VAT rebate policies for exporters many times, providing intertemporal variation that is exploited in this study.
} 
Chinese firms with strong ties to Beijing. The total number of such visits in a given year and the year before was used to evaluate whether this form of commercial diplomacy mattered, per H8. More visits were hypothesised to lead to more exports, and the expected sign on this variable was positive.

The ninth hypothesis amounts to examining whether complaining about Chinese trade and trade practices pays for EU member states. Antidumping investigations were a common form of collective European action against Chinese exports. Such investigations were almost always initiated in response to a complaint from one or more EU member states, and often a publicly available case file stated which European governments sought the inquiry. We found such information all the way back to 1981, starting initially from the Temporary Trade Barriers Database (TTBD) assembled by Chad Bown. For each EU15 member in every year between 2000 and 2010, we calculated the total number of antidumping investigations undertaken by the European Commission since 1981, which the member state in question had supported initiating. We lagged this stock variable by a year to avoid potential simultaneity problems and used it to check whether the member states that complained obtained more lenient treatment from China for their exporters or faced more retaliation towards their exporters by China. Thus, there was no clear prediction for the sign of estimated parameter for this variable. We are not aware of another study that examined this matter in a similar fashion.

Consistent data on only a subset of Chinese trade policies is available over time, so it was not possible to assemble a comprehensive measure of Chinese policy stance towards European exporters. Instead, we calculated for each EU15 member state in a given year $t$, the total stock of Chinese antidumping actions taken against the exporters of a member state from 1999 until year $(t-1)$. This indicator measured, then, the cumulative propensity of China to target the exports of an EU member state using one particularly high-profile trade policy instrument. At best, this served as a proxy for broader Chinese trade policy stance but there were no guarantees that it did so. Data on Chinese antidumping actions were taken from the TTBD as well and were used to evaluate H10. More Chinese dumping actions were expected to depress the dependent variable; hence, a negative sign was expected.

Table 1 presents the summary statistics for the independent variables used in this study and the associated data sources. As measured by the ratio of the respective standard deviations to means, there was considerable variation across the EU15 member states and over time in the share of their exports sold to China, in the total amounts of state aid awarded, in the match between their export composition and Chinese measures to bolster exports, in the number of high level visits to China, and in the frequency of complaints since 1981 against dumped Chinese imports into Europe. ${ }^{17}$ There was much less variation in hourly compensation costs, nominal exchange rates, and government consumption expenditures by the EU15 member states.

\footnotetext{
${ }^{17}$ The coefficient of variation for all of these variables exceeded 0.5 .
} 


\section{Estimation Results and Implications}

Table 2 reports the fixed effects' regression results, which are the most conservative of the various specifications that we estimated. ${ }^{18}$ The parameter estimates for the full sample of $15 \mathrm{EU}$ member states are presented as well as the sample without Finland and Germany. The removal of these countries markedly alters the magnitude and, in some cases, the signs of the estimated parameters. Our focus, then, will be on the tendencies revealed in the data for the remaining 13 EU member states in the sample. The analysis of the apparently unusual Finnish and German exports will have to wait until a later date.

The theory-motivated, demand-side determinant of European export shares to China is not rejected by the data. In fact, the combined explanatory power of the fixed effects and this benchmark independent variable is only a few percentage points lower than the total explained variation of the more elaborate specifications shown in Table 2. This finding implies that the enduring time-invariant determinants of the EU15's export behaviour (such as language differences, distance, differences in legal and other institutions, etc.) plus China's growing share in world GDP go a long way to explain export performance differences across the EU15 member states and over time.

Higher labour costs, traditionally a concern expressed about the European business environment, are found to dampen export sales to China. The coefficient on this term is negative and statistically significant implying, given the construction of this independent variable, that the inability to match German wage moderation over the past decade has limited the export growth of other EU15 member states to China.

Of the remaining seven hypotheses, the only one that is not rejected by the full sample relates to the impact of making complaints about Chinese dumped exports. The positive and statistically significant estimate of the relevant parameter suggests that the EU member states that acquire a reputation for criticising Chinese trade practices by encouraging the European Commission to launch investigations into dumped Chinese products actually experience greater export growth in the Chinese market. Cowering, it seems, does not pay if reorienting exports towards China is the policy objective.

Once Germany and Finland are dropped from the sample, the number of trade missions and visits by government ministers to China is found to be a positive and statistically significant determinant of export shares. Dropping these two countries nearly doubles the implied impact of such commercial diplomacy. Combining the last two findings suggests that, since 2000, a strategy of complaint at home and engagement in Beijing increases the share of exports shipped to China.

\footnotetext{
${ }^{18}$ To assess the validity of the reported findings, alternative specifications without fixed effects for exporters were estimated. Also, different standard error assumptions, including robust-clustered standard errors, were used in robustness checks. All alternative specifications yielded qualitatively similar results.
} 
Moving from statistical significance to quantitative or economic significance, using the parameter estimates from the fixed effects regressions in the sample without Germany and Finland, the relative importance of the factors responsible for the changed shares of EU15 exports shipped to China between 2008 to 2010 in the crisis era, See table 3. This table sheds light on how much of the observed changes in exports are due to, say, less controversial factors such as shifting global spending patterns and potentially more contentious policy choices.

The numbers in Table 3 report, on the basis of the estimated coefficients and the change in an independent variable for a given EU15 country between 2008 and 2010, the percentage of the total change in that country's export share to China over the same time frame which is due to the change in the independent variable. What is striking is the large percentage of observed export share changes that are due to China's growing share in world GDP. China's economy grew faster than the world economy during the years 2008 and 2010 and the implied increase in China's share in world demand alone accounted on average for 68.8 percent of the increase in the EU15 export shares to China. Moreover, had relative labour compensation costs in 2010 been at their 2008 levels, the average share of EU15 exports to China would have been 14.2 percent higher. Had government consumption spending not risen from 2008 to 2010, the average share of the EU's exports to China would have been approximately 5 percent lowera finding which suggests that exporters benefited from national stimulus packages. Finally, had China not decided to expand its use of VAT rebates, Chinese demand for imports would not have been skewed further away from those the EU15 tends to supply. For these Chinese export promotion policies, however, the average share of EU15 exports to China would have been just under 9 percent higher.

While the average impact of bringing complaints to the European Commission about Chinese exports is relatively small, this masks important variation across the EU15. France, the Netherlands, and Spain would have seen their export shares reduced by more than a tenth had they not so frequently complained about Chinese dumping. Chinese antidumping actions against France reduced the latter's export share to China by one-fourteenth or 7 percent. On the other hand, frequent visits by French and Luxembourg ministers to Beijing have raised those countries' share of exports sent to China by a tenth and a sixth respectively, suggesting that commercial diplomacy still had leverage in the crisis era.

With decompositions reported in Table 3, it is possible to assess for each member state the relative importance of the different factors that were responsible for the changing export shares to China witnessed during the first years of the global economic crisis. Since member states varied, the factors holding back their economies' exports to China differed. Examples were the differences in crisis-era wage movements in these countries between 4 and 58 percent of the observed changes in national export shares to China, which accounted for different trajectories in relative labour compensation levels.

Although some concerns have already been raised about data quality, readers might want to take account of the following caveats as well. First, here we focus on the time-varying 
determinants of export shares to China. In principle, there may be other, quantitatively important determinants that do not vary over time. While our use of fixed effects controls the latter, nothing is revealed about their underlying nature or causes. Policymakers may well be interested in these long-standing determinants of export performance as well.

Second, like other empirical researchers in international trade, we are hampered by the lack of annual data on national trade policy stance. Data on only a few trade policy instruments have been collected over many years. In an earlier draft of this paper we employed data from the Global Trade Alert ${ }^{19}$ for the crisis years in our sample (2009 and 2010), specifically data on different types of protectionist measures taken by China against the EU member states. Although such data is available, we concluded (after considerable efforts on our part) that there was insufficient cross-sectional and inter-temporal variation to confidently estimate the effects of crisis-era Chinese protectionism.

A third concern is that changes in an independent variable may have effects over several years, not just in the year of implementation. Although various lag structures were employed, we cannot know whether the period-by-period changes in export shares were correctly attributed to the changes in the independent variables. No doubt some may be concerned about other time-series considerations but, like almost all empirical analyses of bilateral trade flows, we set them to one side.

\section{Concluding Remarks}

During 2012 and 2013 trade relations between the European Union and China deteriorated. Moreover, concerns continued to be expressed that EU countries needed to undertake more supply-side reforms if exports were to make a greater contribution to national economic recoveries. Both of these observations begged the question: What factors were holding back EU exports to fast-growing emerging markets, such as China? The goal of this paper was to shed light on this question and 10 competing hypotheses were formulated to give some structure to the empirical analysis. These hypotheses covered a range of potential demand-side, supplyside, and policy determinants of European exports to China. A novelty of this paper is that the range of policy-related factors it considers is wider than that in most papers. It also includes policies (subsidies and Chinese exchange rate management), which have been the subject of controversy since the onset of the global economic crisis.

Perhaps the most important finding is that, while there is much talk of commercial policies and competitiveness affecting European export performance, by far the most important factor increasing the share of EU exports shipped to China is the fact that the latter's economy

\footnotetext{
${ }^{19}$ An independent trade monitoring initiative sponsored by the Centre for Economic Policy Research (CEPR).
} 
continued to grow faster than the world average. China's spending clout is rising and, not surprisingly, more European exports are shipped to meet growing Chinese needs. To researchers of international trade patterns this is a confirmation of the importance of a factor that is embedded in many models of international trade, including many variants of the gravity equation of bilateral trade flows, which is not often analysed independently.

That global shifts in demand are important, however, does not imply that other considerations are inconsequential. Relatively high levels of labour compensation retarded EU exports to China. Some policies mattered too as Chinese export management policies reduced the shares of exports that the EU15 shipped to China during the early years of the crisis by skewing Chinese demand away from the types of goods that Europe tended to export. Other policies didn't create much effect. Those expecting that European subsidies would help reorient exports towards the fast-growing Chinese market will be disappointed. Moreover, whatever "manipulation" China undertook of its exchange rate did not appear to have been holding back the growth of European export shares to the Middle Kingdom.

One of the most intriguing findings in this study is that EU member states that have over the years called for more antidumping investigations of Chinese exports appear to have their own exports to China treated more leniently by Beijing. Complaining pays, it seems; so do ministerial visits to Beijing. Should other analyses bear out these findings, no doubt some analysts and policymakers will draw the conclusion that a Jekyll and Hyde approach to managing commercial relations with China delivers export sales. If that is so, then the prospects for harmonious EU and Chinese trade relations look slim.

Received 25 June 2013, Revised 31 July 2013, Accepted 5 August 2013

\section{References}

Anderson (1979). James E. Anderson. "A Theoretical Foundation for the Gravity Equation.” American Economic Review 69 (March): 106-16.

Baldwin (2009). Richard E. Baldwin (ed.) The Great Trade Collapse: Causes, Consequences and Prospects. CEPR. 27 November.

Baldwin and Taglioni (2006). Richard E. Baldwin and Daria Taglioni. "Gravity for Dummies and Dummies for Gravity.” Mimeo. Graduate Institute, Geneva.

Davidson and Mackinnon (2003). Russell Davidson and James G. Mackinnon. Econometric Theory and Practice. Oxford University Press.

Eaton, Kortum, Neiman, and Romalis (2011). Jonathan Eaton, Samuel Kortum, Brent Neiman, and John Romalis. "Trade and the Global Recession.” NBER Working Paper No. 16666. January 2011.

Evenett, Fritz, and Yang (2012). Evenett, Simon J, Johannes Fritz, and Yang Chun Jing, "Beyond Dollar Exchange Rate Targeting: China's Crisis-Era Export Management Regime," Oxford Review of Economic 
Policy. Volume 28(2): 284-300.

Feenstra (2003). Robert C. Feenstra. Advanced International Trade: Theory and Evidence. Princeton University Press.

Hunter (1991). Linda Hunter. "The Contribution of Non-Homothetic Preferences to Trade," Journal of International Economics, 30:345-358.

Hunter and Markusen (1988). Linda Hunter and James Markusen. "Per capita Income as a Determinant of Trade," In Robert C. Feenstra (ed.) Empirical Methods for International Economics. MIT Press, Cambridge.

Kee, Neagu, and Nicita (2010). Kee, Hiau Looi, Criistina Neagu, and Alessandro Nicita. "Is protectionism on the rise? Assessing national trade policies during the crisis of 2008," Review of Economics and Statistics.

Krugman (1991). Paul Krugman. "Increasing Returns and Economic Geography," Journal of Political Economy, vol. 99(3), pages 483-99, June.

Leamer and Levinsohn (1995). Edward E. Leamer and James Levinsohn. "Testing Trade Theory.” In G. M. Grossman \& K. Rogoff (eds.), Handbook of International Economics, edition 1, volume 3, chapter 26, pages 1339-1394 Elsevier.

Linder (1961). Steffan Linder. An Essay on Trade and Transformation. Wiley, New York.

PWC (2013). PriceWaterhouseCoopers. "World in 2050". January. 
Figure 1. The growth of EU15 exports to China and the Rest of the World

(2000 2008 and 2008 2010)

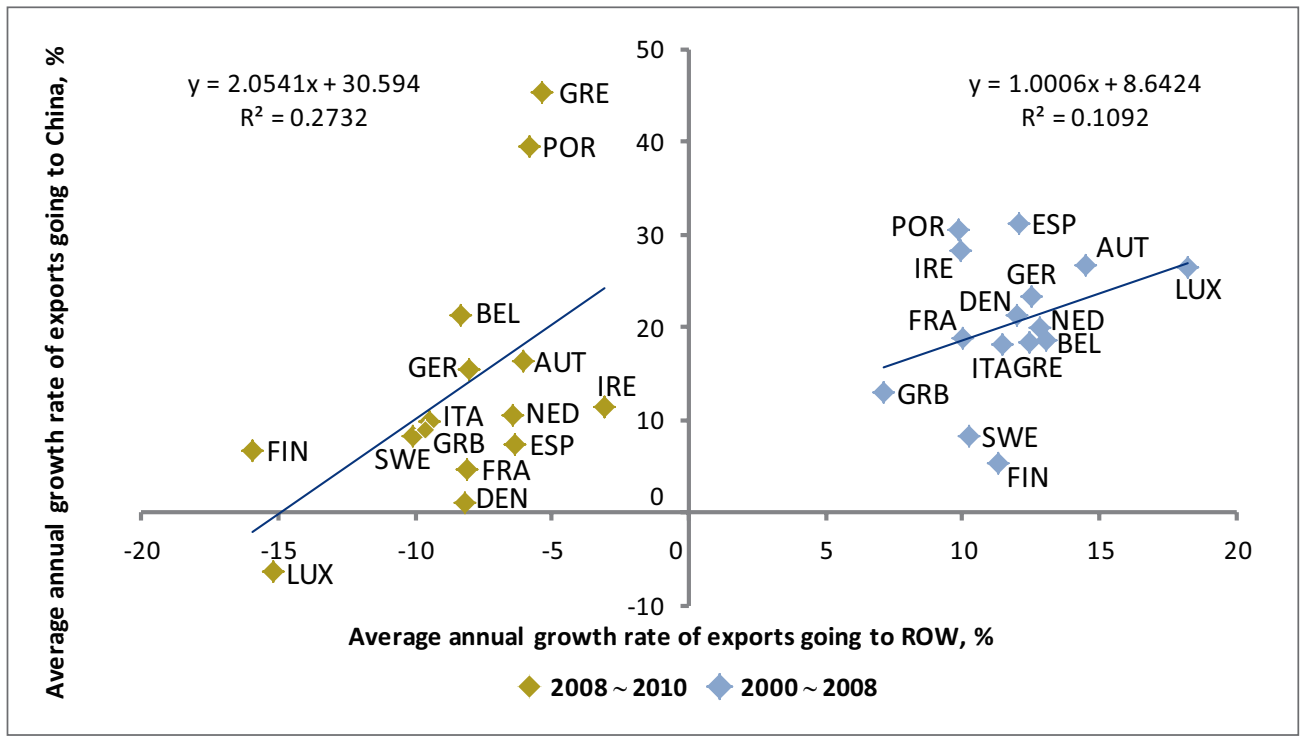

(Note) ROW : Rest of the World

Figure 2. Some convergence in EU15 export shares to China

(2008 2010)

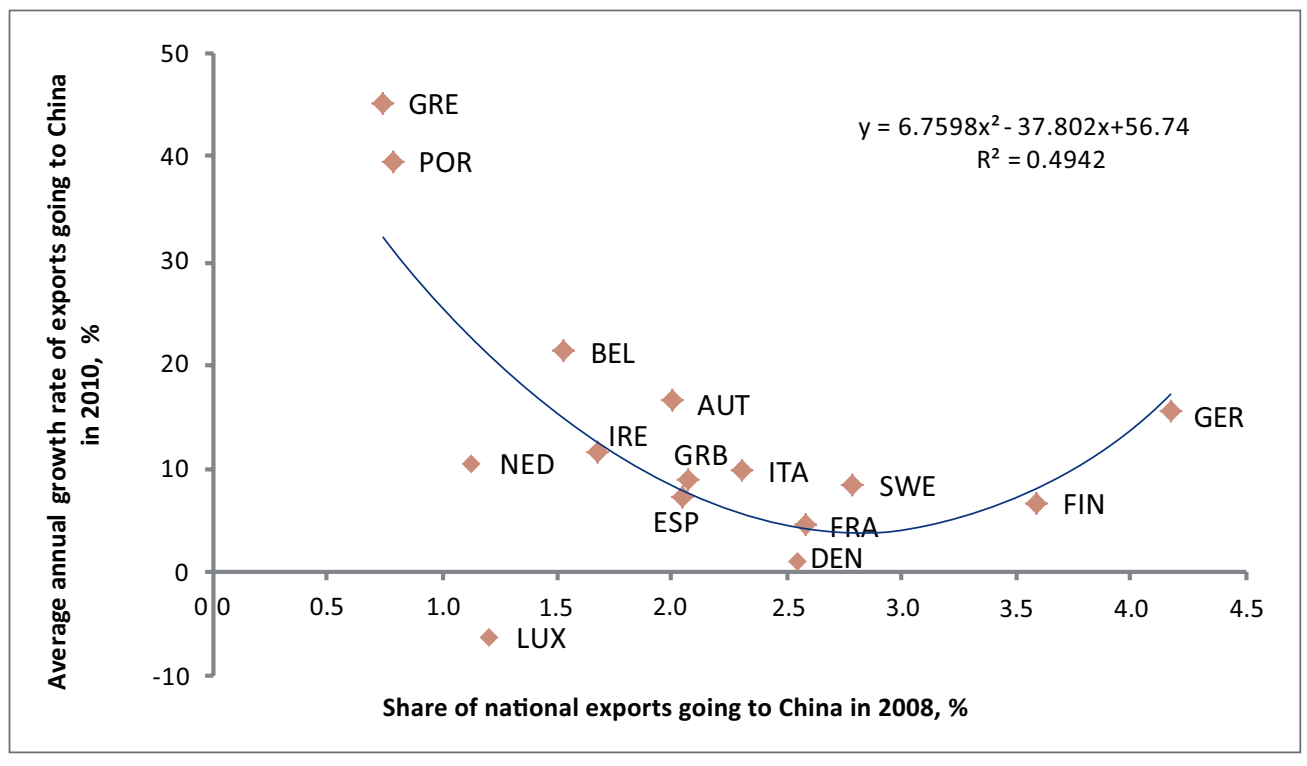

(Note) With the exception of Germany and Finland 
Table 1. Descriptive statistics and data sources

\begin{tabular}{|c|c|c|c|c|c|c|}
\hline Variable & $\begin{array}{c}\text { Number of } \\
\text { observations }\end{array}$ & Mean & $\begin{array}{l}\text { Standard } \\
\text { Deviation }\end{array}$ & Minimum & Maximum & Source \\
\hline $\begin{array}{l}\text { Share of national exports } \\
\text { going to China, in } \%\end{array}$ & 165 & 1.93 & 1.21 & 0.20 & 6.42 & WITS, Comtrade \\
\hline $\begin{array}{l}\text { Government consumption } \\
\text { expenditure, normalised } \\
\text { by GDP }\end{array}$ & 165 & 0.21 & 0.03 & 0.14 & 0.30 & World Bank \\
\hline $\begin{array}{l}\text { Total non-crisis state-aid } \\
\text { (excluding agriculture, } \\
\text { fishery, and transport), } \\
\text { normalised by GDP }\end{array}$ & 165 & 0.45 & 0.24 & 0.10 & 1.30 & $\begin{array}{l}\text { European } \\
\text { Commission, } \\
\text { DG Competition }\end{array}$ \\
\hline $\begin{array}{l}\text { Hourly compensation } \\
\text { costs in manufacturing, } \\
3 \text { lags, indexed } \\
(100=\text { Germany in } 1997)\end{array}$ & 165 & 86.71 & 32.17 & 20.09 & 163.88 & $\begin{array}{l}\text { United States Bureau } \\
\text { of Labor Statistics }\end{array}$ \\
\hline $\begin{array}{l}\text { Difference in } \\
\text { composition index }\end{array}$ & 165 & 0.15 & 0.07 & 0.02 & 0.35 & WITS, Comtrade \\
\hline $\begin{array}{l}\text { Share of VAT } \\
\text { export rebates of total } \\
\text { exports, in \% }\end{array}$ & 165 & 2.91 & 0.66 & 1.87 & 4.31 & $\begin{array}{l}\text { State Administration } \\
\text { of Taxation of China; } \\
\text { National Bureau of } \\
\text { Statistics of China }\end{array}$ \\
\hline $\begin{array}{l}\text { Interaction term of share } \\
\text { of VAT export rebates } \\
\text { and difference in } \\
\text { composition index }\end{array}$ & 165 & 0.45 & 0.23 & 0.05 & 1.15 & See above \\
\hline $\begin{array}{l}\text { China's share of world } \\
\text { GDP, in \% }\end{array}$ & 165 & 5.75 & 1.85 & 3.71 & 9.39 & World Bank \\
\hline $\begin{array}{l}\text { Nominal exchange rate, } \\
\text { indexed }(2,000=100)\end{array}$ & 165 & 121.74 & 15.67 & 85.10 & 140.73 & $\begin{array}{l}\text { European Central } \\
\text { Bank (ECB) }\end{array}$ \\
\hline $\begin{array}{l}\text { Number of high-level } \\
\text { visits to China, current } \\
\text { and } 1 \text { year lag }\end{array}$ & 165 & 1.59 & 1.79 & 0 & 9 & Factiva \\
\hline $\begin{array}{l}\text { Number of initiations } \\
\text { of AD investigations } \\
\text { against China } \\
\text { (by nationality of } \\
\text { complaining firms), ever } \\
\text { initiated, } 1 \text { year lag }\end{array}$ & 165 & 12.10 & 14.09 & 0 & 51 & $\begin{array}{l}\text { Temporary Trade } \\
\text { Barriers Database } \\
\text { (Chad Bown) }\end{array}$ \\
\hline $\begin{array}{l}\text { Number of initiations } \\
\text { of AD investigations by } \\
\text { China, ever initiated, } \\
1 \text { lag }\end{array}$ & 165 & 0.99 & 1.81 & 0 & 8 & $\begin{array}{l}\text { Temporary Trade } \\
\text { Barriers Database } \\
\text { (Chad Bown) }\end{array}$ \\
\hline
\end{tabular}


Table 2. Parameter estimates for the first stage regression

Dependent variable: Share of national exports going to China, $\%$

(2000 2010)

\begin{tabular}{|c|c|c|c|}
\hline Hypothesis & Parameter & EU15 & $\begin{array}{l}\text { w/o Germany } \\
\text { and Finland }\end{array}$ \\
\hline $\mathrm{H} 1, ?$ & $\begin{array}{l}\text { Government consumption expenditure, } \\
\text { normalised by GDP }\end{array}$ & $\begin{array}{l}-1.047 \\
(4.234)\end{array}$ & $\begin{array}{c}4.944 \\
(3.437)\end{array}$ \\
\hline $\mathrm{H} 2, ?$ & $\begin{array}{l}\text { Total non-crisis state-aid (excluding agriculture, } \\
\text { fishery, and transport), normalised by GDP }\end{array}$ & $\begin{array}{l}-0.410^{*} \\
(0.243)\end{array}$ & $\begin{array}{l}-0.269 \\
(0.227)\end{array}$ \\
\hline $\mathrm{H} 3,-$ & $\begin{array}{l}\text { Hourly compensation costs in manufacturing, } \\
3 \text { lags, indexed ( } 100=\text { Germany in 1997) }\end{array}$ & $\begin{array}{l}-0.0101 * * * \\
(0.00348)\end{array}$ & $\begin{array}{l}-0.00680 * * \\
(0.00265)\end{array}$ \\
\hline $\mathrm{H} 4,-$ & Difference in composition index & $\begin{array}{c}0.973 \\
(2.048)\end{array}$ & $\begin{array}{c}2.084 \\
(1.283)\end{array}$ \\
\hline $\mathrm{H} 5,-$ & $\begin{array}{l}\text { Interaction term of share of VAT export rebates } \\
\text { and difference in composition index }\end{array}$ & $\begin{array}{l}-0.357 \\
(0.598)\end{array}$ & $\begin{array}{l}-0.687^{*} \\
(0.412)\end{array}$ \\
\hline $\mathrm{H} 6,+$ & China's share of world GDP, in \% & $\begin{array}{l}0.326 * * * \\
(0.0629)\end{array}$ & $\begin{array}{l}0.310 * * * \\
(0.0509)\end{array}$ \\
\hline $\mathrm{H} 7,-$ & Nominal exchange rate, indexed $(2,000=100)$ & $\begin{array}{c}-0.00357 \\
(0.00270)\end{array}$ & $\begin{array}{l}0.000420 \\
(0.00152)\end{array}$ \\
\hline $\mathrm{H} 8,+$ & $\begin{array}{l}\text { Number of high-level visits to China, } \\
\text { current and } 1 \text { lag }\end{array}$ & $\begin{array}{c}0.0213 \\
(0.0225)\end{array}$ & $\begin{array}{l}0.0385^{*} \\
(0.0200)\end{array}$ \\
\hline $\mathrm{H} 9$,? & $\begin{array}{l}\text { Number of initiations of AD investigations } \\
\text { against China (by nationality of complaining } \\
\text { firms), ever initiated, } 1 \text { lag }\end{array}$ & $\begin{array}{l}0.0398 * * * \\
(0.0142)\end{array}$ & $\begin{array}{l}0.0163 * * \\
(0.00763)\end{array}$ \\
\hline $\mathrm{H} 10,-$ & $\begin{array}{l}\text { Number of initiations of } \mathrm{AD} \text { investigations } \\
\text { by China, ever initiated, } 1 \text { lag }\end{array}$ & $\begin{array}{c}0.0348 \\
(0.0545)\end{array}$ & $\begin{array}{l}-0.0530 \\
(0.0456)\end{array}$ \\
\hline & Constant & $\begin{array}{l}1.412 \\
(1.000)\end{array}$ & $\begin{array}{l}-0.354 \\
(0.700)\end{array}$ \\
\hline & Observations & 165 & 143 \\
\hline & $\mathrm{R}$-squared & 0.925 & 0.929 \\
\hline
\end{tabular}

(Note) $* * * p<0.01, * * p<0.05, * p<0.1$ 
Table 3. Contribution of each independent variable to changes in share of exports to China

(2008 2010)

(Unit: \%)

\begin{tabular}{|c|c|c|c|c|c|c|c|c|}
\hline Hypothesis & Variable & Median & Austria & Belgium & Denmark & France & Greece & Ireland \\
\hline \multirow{2}{*}{$\begin{array}{l}\text { (Dependent } \\
\text { variable) }\end{array}$} & $\begin{array}{l}\text { Change in share of national exports } \\
\text { to China between } 2008 \sim 2010 \text {, } \\
\text { in percentage points }\end{array}$ & 0.90 & 1.04 & 1.12 & 0.52 & 0.74 & 0.99 & 0.53 \\
\hline & $\begin{array}{l}\text { Change in share of national } \\
\text { exports to China between } \\
2008 \sim 2010 \text {, in \% }\end{array}$ & 43.27 & 51.92 & 72.78 & 20.28 & 28.56 & 133.80 & 31.53 \\
\hline $\mathrm{H} 1$ & $\begin{array}{l}\text { Government consumption } \\
\text { expenditure, normalized by GDP }\end{array}$ & 5.69 & 3.38 & 4.75 & 24.20 & 10.73 & 0.28 & 2.77 \\
\hline $\mathrm{H} 2$ & $\begin{array}{l}\text { Total non-crisis state-aid } \\
\text { (excluding agriculture, fishery, and } \\
\text { transport), normalized by GDP }\end{array}$ & -2.59 & -2.59 & -4.82 & -5.20 & -7.31 & -8.13 & -5.07 \\
\hline $\mathrm{H} 3$ & $\begin{array}{l}\text { Hourly compensation costs } \\
\text { in manufacturing, } 3 \text { lags, } \\
\text { indexed (100=Germany in 1997) }\end{array}$ & -14.21 & -13.49 & -13.58 & -31.64 & -18.45 & -10.50 & -24.83 \\
\hline $\mathrm{H} 4$ & Difference in composition index & 2.39 & -0.01 & 1.30 & 6.12 & 0.28 & 5.21 & 16.01 \\
\hline H5 & $\begin{array}{l}\text { Interaction term of share of VAT } \\
\text { export rebates and difference } \\
\text { in composition index }\end{array}$ & -8.70 & -3.07 & -6.76 & -12.96 & -5.13 & -12.94 & -29.19 \\
\hline H6 & China's share of world GDP, in \% & 68.79 & 59.77 & 55.71 & 120.34 & 84.48 & 62.68 & 117.15 \\
\hline $\mathrm{H} 7$ & $\begin{array}{l}\text { Nominal exchange rate, } \\
\text { indexed }(2,000=100)\end{array}$ & -0.92 & -0.68 & -0.63 & -1.35 & -0.96 & -0.71 & -1.33 \\
\hline H8 & $\begin{array}{l}\text { Number of high-level visits to } \\
\text { China, current and } 1 \text { lag }\end{array}$ & 0.00 & 3.70 & -3.45 & 0.00 & 10.46 & -3.88 & 0.00 \\
\hline H9 & $\begin{array}{l}\text { Number of initiations of } \mathrm{AD} \\
\text { investigations against China } \\
\text { (by nationality of complaining } \\
\text { firms), ever initiated, } 1 \text { lag }\end{array}$ & 3.47 & 3.13 & 5.84 & 0.00 & 15.50 & 1.64 & 0.00 \\
\hline $\mathrm{H} 10$ & $\begin{array}{l}\text { Number of initiations of } \mathrm{AD} \\
\text { investigations by China, } \\
\text { ever initiated, } 1 \text { lag }\end{array}$ & 0.00 & 0.00 & 0.00 & 0.00 & -7.20 & 0.00 & 0.00 \\
\hline
\end{tabular}


Table 3 (continued)

\begin{tabular}{|c|c|c|c|c|c|c|c|c|c|}
\hline Hypothesis & Variable & Median & Italy & Luxembourg & Netherlands & Portugal & Spain & Sweden & $\begin{array}{l}\text { United } \\
\text { Kingdom }\end{array}$ \\
\hline \multirow{2}{*}{$\begin{array}{l}\text { (Dependent } \\
\text { variable) }\end{array}$} & $\begin{array}{l}\text { Change in share of } \\
\text { national exports to China } \\
\text { between 2008 2010, } \\
\text { in percentage points }\end{array}$ & 0.90 & 1.05 & 0.26 & 0.44 & 0.94 & 0.62 & 1.21 & 0.90 \\
\hline & $\begin{array}{l}\text { Change in share of } \\
\text { national exports to China } \\
\text { between 2008 2010, in \% }\end{array}$ & 43.27 & 45.24 & 21.43 & 39.11 & 117.75 & 30.26 & 43.27 & 43.76 \\
\hline H1 & $\begin{array}{l}\text { Government consumption } \\
\text { expenditure, normalized } \\
\text { by GDP }\end{array}$ & 5.69 & 5.00 & 34.94 & 31.01 & 8.00 & 12.73 & 2.86 & 5.69 \\
\hline $\mathrm{H} 2$ & $\begin{array}{l}\text { Total non-crisis state-aid } \\
\text { (excluding agriculture, } \\
\text { fishery, and transport), } \\
\text { normalized by GDP }\end{array}$ & -2.59 & 2.57 & -10.34 & 0.00 & 0.00 & 0.00 & 0.00 & 0.00 \\
\hline $\mathrm{H} 3$ & $\begin{array}{l}\text { Hourly compensation } \\
\text { costs in manufacturing, } \\
3 \text { lags, indexed } \\
(100=\text { Germany in } 1997)\end{array}$ & -14.21 & -9.03 & -58.30 & -22.96 & -4.11 & -15.21 & -13.84 & -14.21 \\
\hline $\mathrm{H} 4$ & $\begin{array}{l}\text { Difference in composition } \\
\text { index }\end{array}$ & 2.39 & 3.71 & 2.31 & 5.36 & 1.70 & 2.39 & 1.00 & 3.85 \\
\hline H5 & $\begin{array}{l}\text { Interaction term of share } \\
\text { of VAT export rebates } \\
\text { and difference in } \\
\text { composition index }\end{array}$ & -8.70 & -8.70 & -17.67 & -13.67 & -8.42 & -10.22 & -3.71 & -8.16 \\
\hline H6 & $\begin{array}{l}\text { China's share of world } \\
\text { GDP, in \% }\end{array}$ & 68.79 & 59.47 & 239.11 & 140.56 & 66.27 & 100.17 & 51.54 & 68.79 \\
\hline $\mathrm{H} 7$ & $\begin{array}{l}\text { Nominal exchange rate, } \\
\text { indexed }(2,000=100)\end{array}$ & -0.92 & -0.67 & -2.71 & -1.59 & -0.75 & -1.14 & -0.45 & -0.92 \\
\hline H8 & $\begin{array}{l}\text { Number of high-level } \\
\text { visits to China, current } \\
\text { and } 1 \text { lag }\end{array}$ & 0.00 & -3.68 & 14.80 & 8.70 & 0.00 & 0.00 & -3.19 & 8.52 \\
\hline H9 & $\begin{array}{l}\text { Number of initiations of } \\
\text { AD investigations against } \\
\text { China (by nationality of } \\
\text { complaining firms), } \\
\text { ever initiated, } 1 \text { lag }\end{array}$ & 3.47 & 9.35 & 6.27 & 11.05 & 3.47 & 13.13 & 1.35 & 0.00 \\
\hline $\mathrm{H} 10$ & $\begin{array}{l}\text { Number of initiations of } \\
\text { AD investigations by } \\
\text { China, ever initiated, } 1 \text { lag }\end{array}$ & 0.00 & -5.07 & 0.00 & 0.00 & 0.00 & 0.00 & 0.00 & -5.86 \\
\hline
\end{tabular}

